POLITEJA

nr 1(58), 2019, s. 15-29

https://doi.org/10.12797/Politeja.16.2019.58.02

\title{
Irena SZLACHCICOWA
}

Uniwersytet Wrocławski

i.szlachcicowa@gmail.com

\section{BORDERSCAPES - KRAJOBRAZY GRANIC JAKO NOWA PERSPEKTYWA BADAŃ}

\section{ABSTRACT Borderscapes - Borders' Landscapes as a New Research Perspective}

The last two decades brought a marked change in the way the border is understood. There was also a revival of discussion about the historical and social context of the border creation and functioning, which resulted in opening new theoretical perspectives. The concept of borderscapes is an attempt to complement and enrich the current way of thinking about borders by emphasizing the role of social and cultural aspects of shaping the space around borders. The inspiration for new ideas was both spatial and relational turn taking place in social sciences at the turn of the century. The aim of this article is to present the original way of conceptualizing and testing boundaries labeled as borderscapes. The perspective of borderscape brings a new view on reality and seeks theoretical and empirical possibilities to capture the complex, multidimensional social space that the borders set. This approach attempts to show the border as a dynamic transnational space of relations, discourses and social practices.

Keywords: borderscapes, space, border, processual ontology, social construction of borders

Słowa kluczowe: krajobrazy przygraniczne, przestrzeń, granica, procesualna ontologia, społeczne tworzenie granic 
C poka globalizacji, przynosząc rozpad tradycyjnych form społecznego ładu i kreu-

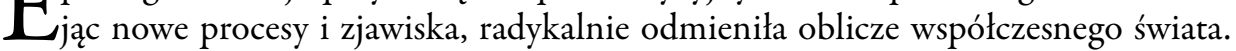
Rzeczywistość, „odczarowana” z modernistycznych przekonań o człowieku, wspólnocie i etosie, utraciła swój spójny, regularny i stabilny charakter. W zglobalizowanym, ponowoczesnym świecie prymat zyskuje płynność, przygodność i pluralizm. Społeczną egzystencję określa nade wszystko zmiana i permanentna mobilność, wizja otwierającej się przestrzeni, tak w dosłownym, jak i metaforycznym tego słowa znaczeniu. Mobilność przestrzenna i społeczna towarzyszy współcześnie wszelkim formom ludzkiej egzystencji. Nieustanny rozwój technologii i nasycenie nią praktyk życia codziennego uwalnia od miejsca i umożliwia swobodną jego zmianę. Odmieniona i pozostająca w ruchu rzeczywistość nie poddaje się jednoznacznej definicji, jej obraz staje się coraz bardziej złożony, ukazując wielość perspektyw. Różnorodność i zmienność otwierającej się przestrzeni życia w procesie zderzenia kulturowych różnic łączy i rozdziela zarazem, prowadzi do integracji bądź wzbudza konflikty, tworząc nowe krajobrazy wędrujących kultur.

Procesy globalizacji powodujące zmianę funkcji państwa narodowego i tworzenie struktur ponadpaństwowych ukazują ogólną tendencję do unifikacji i znoszenia granic. Granica przestaje być symbolem kresu terytorium państw-narodów, krawędzią oddzielającą sąsiadujące ze sobą społeczności o różnej politycznej i etnicznej tożsamości. Efektem tego jest polityka otwierania granic między państwami realizowana w ramach programu jednoczenia Europy. Na zjawisko zanikania granic zwraca się uwagę głównie w kontekście dokonujących się procesów integracji i globalizacji, jednocześnie coraz silniejszy nacisk położony jest na denaturalizowanie i demistyfikowanie społecznych różnic i wynikających z nich ograniczeń. Z jednej strony ciągle podtrzymywana i ożywiana jest idea integracji i zespalania, ale z drugiej, wraz z kolejnymi falami migracji i rosnącą liczbą zamachów terrorystycznych, zwiększa się napięcie wokół granic i pojawia się pokusa ponownego ich wyraźnego dookreślenia.

Problematyka granic nabiera obecnie coraz większego znaczenia. W czasach późnej nowoczesności, pomimo stale rosnącego zróżnicowania i płynności społecznych światów, gdy wprost artykułowane są procesy otwierania i rozpuszczania granic, terytorialne podziały, utrwalone i zobiektywizowane w postaci map, nadal sankcjonują polityczny układ międzypaństwowych granic. Granice dostrzegane i problematyzowane są niemal w każdym wymiarze życia społecznego. Mówimy często i z łatwością nie tylko o granicach państwowych, ale i społecznych, kulturowych czy symbolicznych. Tych rzeczywistych, posiadających swoje materialne manifestacje, i tych wyobrażonych, pozostających w sferze imaginacji. Termin „granica” funkcjonuje w całej swej wieloznaczności zarówno w języku potocznym, jak i naukowym. Tajemnicą pozostanie jednak, na ile wzrost zainteresowania i skłonność do przywoływania go w dyskursie naukowym wynika z faktycznej potrzeby, a na ile z panującej mody i stanowi wyraz szczególnego border boom, z którym mamy obecnie do czynienia. Czasami można odnieść wrażenie, że jest to pojęcie nadużywane i w efekcie tego zbanalizowane, a jego znaczenie ulega rozmyciu.

Celem artykułu jest przedstawienie oryginalnego sposobu konceptualizowania i badania granic, który wypracowany został w ramach teorii kulturowych krajobrazów 
przygranicznych. Perspektywa borderscapes wnosi nowe spojrzenie na rzeczywistość oraz poszukuje możliwości teoretycznego i empirycznego uchwycenia złożonej, wielowymiarowej przestrzeni społecznej, którą wyznacza granica. Podejście badawcze dąży do ukazania procesów konstruowania społecznych granic i powiązanych z nimi tożsamości. Akceptacja takiego nastawienia prowokuje do postawienia następujących pytań. Na czym polega novum teoretycznych rozważań o granicy? Czym skutkuje przyjęcie procesualnej i relacyjnej koncepcji rzeczywistości społecznej i jak w tym kontekście zmienia się sposób badania współczesnych granic? ${ }^{1}$

\section{MAPY I GRANICE}

Mapa stanowi zobiektywizowane narzędzie porządkowania przestrzeni, które narzuca sposób percepcji, nazywania i kategoryzowania rzeczywistości. Obiektywny charakter mapy - postrzegany jako umowny bądź rzeczywisty - jest wynikiem uprawomocnienia określonych reguł tworzenia porządku. Niezbywalnym filarem tego uprawomocnienia jest nie tylko przypisanie do określonego terytorium, ale również zakorzenienie we władzy. Jednocześnie mapa daje złudzenie, że granice są neutralnym sposobem uporządkowania przestrzeni geograficznej. Granice jako linie na mapie, kreując usystematyzowany, oficjalnie uznawany obraz świata, strukturyzują sposób doświadczania rzeczywistości. Taki sposób myślenia o naturze społecznego świata, pozostając w zgodzie z tradycyjnym konceptem przestrzeni, jest utrwalany i naturalizowany w procesie socjalizacji i rozpowszechnionych praktykach dyskursu publicznego².

Ustalenie zakresu znaczeniowego terminu "granica” od dawna sprawia badaczom kłopot. W naukowych debatach poświęconych problematyce granic odpowiedź na pytanie, czym jest granica, padała już wielokrotnie. Granicami zainteresowani są nie tylko politolodzy, socjologowie, antropolodzy i inni przedstawiciele nauk społecznych, ale także geografowie, historycy i artyści. Podkreśla się, że jest to pojęcie polisemiczne, posiadające wielorakie odniesienia, częstokroć stosowane w odmiennych kontekstach, i dlatego podatne na różne, nierzadko sprzeczne interpretacje.

W swoim podstawowym, terytorialnym wymiarze przestrzeń fizyczna określona przez geograficzno-historyczne uwarunkowania tworzy układ naturalnych i państwowych granic. Granice państwowe, wyznaczając i nadzorując terytorium państwa, manifestują jego zasięg i suwerenność. Granica jako linia przecinająca nie tylko przestrzeń geograficzną, ale i społeczno-kulturową, rozdziela i ukazuje różnice,

Odpowiedzi na przytoczone pytania poszukiwałam również w artykule Granica jako relacyjna przestrzeń: implikacje teoretyczne, opublikowanym w tomie pokonferencyjnym Transgraniczność w perspektywie socjologicznej: Europa - podzielona wspólnota?, red. M. Zielińska, D. Szaban, B. Trzop, Zielona Góra 2018, s. 43-59. Artykuł - choć wcześniej datowany - stanowi rozszerzoną wersję rozważań o relacyjnym i przestrzennym zwrocie w konceptualizowaniu i badaniu przestrzeni granic, które zamieszczam poniżej.

2 A. Paasi, Bounded Spaces in a 'Borderless World': Border Studies, Power and the Anatomy of Territory, „Journal of Power” 2009, vol. 2, nr 2, s. 226. 
wyznaczając jednocześnie obszar styku jednej społeczności z inną. Umożliwia i kontroluje przepływ ludzi, towarów, idei. Polityczny wymiar granic oraz jego odniesienie do terytorium posiada istotne znaczenie strategiczne i symboliczne. Hastings Donnan i Thomas M. Wilson podkreślają, że granice sa zarówno strukturami, jak i symbolami bezpieczeństwa oraz suwerenności państwa. Stanowia historyczne i wspótczesne zapisy relacji państwa z innymi krajami, z wtasnymi ludźmi i z wtasnym obrazem ${ }^{3}$. Granica z założenia wskazuje na kres i rozdzielenie, ale jest także miejscem styku i kontaktu z innymi. Obrazuje odrębność i współzależność jednocześnie. Na granicy czy też dzięki jej istnieniu następuje spotkanie z tym, co odmienne. Sytuacja spotkania z innym, który niekoniecznie jest obcym, uwidacznia, jak granica funkcjonuje w praktyce. W zależności od miejsca i czasu może pełnić funkcję muru izolującego od świata lub też być mostem, który umożliwia zbliżenie.

Pojęcie granicy często definiowane jest w węższym, terytorialnym czy geograficznym zakresie, ale może też przybierać charakter bardziej abstrakcyjny, posiada wówczas znacznie szersze odniesienie. Granica postrzegana jest wtedy nie jako statyczna i zinstytucjonalizowana struktura między państwami, ale jako społecznie konstruowana, dynamiczna przestrzeń relacji. Przygraniczna przestrzeń, tak jak generuje terytorialne odniesienie, tak też określa i reguluje typy relacji społecznych i wyznacza spektrum grupowych przynależności. Społeczny wymiar granicy ukazuje swoisty układ styczności i zależności, wzajemnego oddziaływania między ludźmi oraz społecznego zróżnicowania. Granica państwowa jako struktura narzucona zewnętrznie zderza się tu z wyobrażeniami i znaczeniami, które są jej przypisywane przez mieszkańców terenów przygranicznych. Sposób postrzegania granicy i nadawane jej znaczenie - w większym lub mniejszym stopniu - implikuje obraz społecznej rzeczywistości oraz kształt tożsamości, tak jednostkowej, jak i zbiorowej. Granice definiowane jako linie kontaktu lub rozdzielenia moga występować w przestrzeni realnej lub wirtualnej, horyzontalnie między terytoriami bądź wertykalnie między grupami i/lub jednostkami. Punkt kontaktu lub separacji zazwyczaj prowadzi do uksztattowania tożsamości zakotwiczonej w podziale „my” $i$ „Oni”. Granica, wyznaczając obszar powiązań między kulturowo odmiennymi społecznościami, staje się punktem odniesienia dla procesów konstruowania tożsamości jednostkowych i szerszych identyfikacji społecznych. Spotkanie z innością, zderzenie oswojonej i obcej przestrzeni społecznej egzystencji to istotny element doświadczenia. Kulturowe i etniczne wspólnoty tworzące przestrzeń pogranicza wyznaczają spektrum znaczeń i wzorów działania oraz ustanawiają granice kulturowej tożsamości.

Granica jako społeczno-kulturowy fenomen stanowi zbiór jednostkowych działań, określających je reguł i norm społecznych, sposobów wartościowania i postrzegania świata. Granice, posiadając kulturowy i symboliczny potencjał, wyrażają kulturową różnorodność społecznych światów, współobecność lub konfrontację odmiennych

H. Donnan, T.M. Wilson, Granice tożsamości, narodu, państwa, przeł. M. Głowacka-Grajper, Kraków 2007, s. 32.

4 D. Newman, A. Paasi, Podziaty i sasiedztwa w ponowoczesnym świecie. Narracje granic w geografii politycznej, przeł. B. Czepil, „Pogranicze. Polish Borderlands Studies” 2013, vol. 1, nr 1, s. 17. 
wzorów i znaczeń. W kulturowym wymiarze granice stanowią byty, które tworzq i nosza w sobie znaczenia: sq częściami kulturowych krajobrazów, które często przekraczaja fizyczne granice państwa i pokonuja site państwowych instytucjis. Silne eksponowanie kulturowych atrybutów granic zwiastuje coraz bardziej widoczne w polu badań odejście od definiowania granicy jako linii rozdzielającej to, co kulturowo, społecznie i politycznie odmienne. Pojęcie różnicy kulturowej traci swoją ostrość i zaczyna być traktowane jako problematyczne. Kultura, społeczeństwo, państwo czy naród nie mogą być już identyfikowane jako spójne, jednoznaczne w swej treści, monolityczne całości, odwołanie do których pozwala rozstrzygać o przynależności i nadawać tożsamość. Przypisanie do kultury narodowej czy terytorium państwa nie może być traktowane jako wystarczająca zmienna wyjaśniająca istnienie różnic $i$ wywodzących się z nich granic. Granice społeczne jako pochodne istniejących i konstytuujących realny świat różnic mają charakter kulturowy i interakcyjny. Tak różnice, jak i granice posiadają wyraźne odniesienie kontekstualne.

Warto wspomnieć o jeszcze jednym, szczególnie istotnym w kontekście proponowanej koncepcji aspekcie granicy. Granica stanowi próg (limen), przekroczenie którego $\mathrm{z}$ jednej strony jest warunkiem wejścia do innego świata społecznego, a z drugiej symbolizuje zerwanie z tym, co zostało opuszczone. Stan liminalny to stan przejścia, które metaforycznie oddaje istotę granicy. Znaczenie słowa „próg” może być odczytane jako wejście, początek czegoś, ale także jako przeszkoda, granica. Oznacza wyłączenie z czegoś, co było dotychczas, oderwanie od tego, co znane i oswojone, i przyłączenie do czegoś nowego, nieznanego, a często postrzeganego jako lepsze. Liminalność jako stadium przejściowe przywodzi na myśl zarówno kres, jak i początek, odseparowanie i wejście, ukazując napięcie między obecnością „w” a pozostawaniem „poza”. Bycie w sferze liminalnej oznacza życie pomiędzy różnymi światami czy kulturami, a ponieważ jest odczuwane jako „ani tu, ani tam”, może oddziaływać wykorzeniająco. Przekraczanie granic, symbolizując wejście w fazę liminalną, zapowiada transformację i wprowadza ambiwalencję. Przejściu z jednego miejsca lub stanu do drugiego towarzyszy okres zawieszenia, swoistej społecznej pustki, braku przynależności i rozmycia tożsamości.

\section{OD „LINII NA PIASKU” KU KRAJOBRAZOM - ZMIANA PERSPEKTYWY TEORETYCZNEJ}

Ostatnie dekady przyniosły zasadniczą zmianę w sposobie pojmowania granicy. Nastąpiło ożywienie dyskusji o historycznym i społecznym kontekście tworzenia i funkcjonowania granic, co zaowocowało projektowaniem nowych perspektyw teoretycznych. Dynamika i charakter zmian zachodzących we współczesnym świecie skłaniają do uznania tezy, że konceptualizowanie granic bazujące jedynie na odniesieniu terytorialnym jest niewystarczające. Zakwestionowanie statycznego definiowania granicy jako linii oddzielającej dwa różne państwa, narody czy kultury coraz częściej prowadzi do optowania

H. Donnan, T.M. Wilson, Granice tożsamości, narodu..., s. 19. 
za postrzeganiem granic w procesie ich konstruowania. Chodzi bowiem o zdecydowane podkreślenie oraz próbę uchwycenia procesualnej i temporalnej natury granic. Akcent położony jest obecnie na postrzeganiu granicy jako dynamicznej, transnarodowej przestrzeni relacji, dyskursów i społecznych praktyk. Granice ujmowane jako społeczno-terytorialne konstrukty nie są stałymi bytami społecznymi czy określającymi je właściwościami, lecz procesami. Dążenie do uchwycenia dynamicznego charakteru istnienia granic w czasie i przestrzeni wymaga zatem porzucenia substancjalnej optyki poznawania rzeczywistości i skłania do wieloperspektywicznego ujęcia problemu.

Proces przemiany w sposobie konceptualizowania granicy najlepiej ilustruje konwersja pojęć. Pojęcie granicy (border) przekształcone zostaje w pojęcie graniczenia (bordering). Terminologiczna metamorfoza $\mathrm{z}$ granicy na procesy graniczenia dobrze oddaje zmianę w sposobie myślenia o granicach w dobie globalizacji i wzmożonej mobilności. Celem poszukiwań badawczych staje się teraz nie tyle odtworzenie mapy, co ukazanie granic $\mathrm{w}$ procesie ich tworzenia i poznanie różnorodnych procesów generujących różnice i nierówności społeczne oraz towarzyszących im mechanizmów dominacji, które prowadzą do petryfikowania i artykułowania granic. Dopiero takie podejście, definiujące granice jako rezultat społecznych praktyk ich wytwarzania, pozwala na ukazanie granic $\mathrm{w}$ ich procesualnych i złożonych (terytorialnych, politycznych, kulturowych, społecznych) manifestacjach.

Teoretyczne poszukiwania uczonych, czyniących przedmiotem swoich zainteresowań granice, odzwierciedlają dylematy i pytania stawiane pod adresem nauk społecznych w ogóle. Inspirację i pożywkę dla nowych idei stanowią zarówno zwrot przestrzenny (spatial turn), jak i relacyjny (relational turn), mające miejsce w naukach społecznych, czy - ujmując rzecz nieco szerzej - w całej humanistyce, na przełomie wieków. Zwrot przestrzenny ilustruje nie tylko wzrost zainteresowania przestrzenią, odkrywanie istotności kontekstu przestrzennego dla poznania zjawisk społecznych, ale przede wszystkim prowadzi do jej redefiniowania. Wskazywano, że pojęcie przestrzeni jest pojęciem wieloznacznym i budzącym liczne skojarzenia, co uświadamia nader jasno problematyczność jej postrzegania. Ponadto wysuwano liczne zastrzeżenia do sposobu wykorzystania pojęcia przestrzeni w dyskursie akademickim, podkreślając, że jest ono rozumiane zbyt schematycznie i błędnie uznawane za pojęcie neutralne. Doprecyzowanie pojęcia przestrzeni jest tym bardziej pożądane, że stwarza szansę na lepsze poznanie procesów społecznych w dobie globalizacji. Zasadnicza zmiana sposobu myślenia o przestrzeni oznacza odrzucenie tezy o jej statycznym, zamkniętym i obiektywnym charakterze, a w konsekwencji afirmację sądów o jej otwartości, heterogeniczności i nieuchronnej dynamice.

Zwrot przestrzenny dokonujący się w naukach społecznych, podobnie jak zwrot relacyjny, wyrasta z krytyki klasycznych teorii społecznych bazujących na statycznym postrzeganiu rzeczywistości. Statyka społeczna kojarzona jest przede wszystkim z teoriami strukturalistycznymi, które utrwaliły sposób myślenia o rzeczywistości poprzez rozdzielenie czasu od przestrzeni. Skutkuje to nieuzasadnionym uprzywilejowaniem kategorii czasu wobec przestrzeni. Bifurkacja trwania i przestrzeni sprawia, że przestrzeń jest postrzegana jako fizykalne dopełnienie uwewnętrznionej temporalności, co wzmacnia myślenie o świecie za pomocą opozycyjnych schematów jednostka-świat; 
wewnętrzne-zewnętrzne; subiektywny-obiektywny. Przestrzeń ujmowana jest nieruchomo, jako nakładające się na siebie płaty upływającego czasu, ukazujące zastygły w bezruchu obraz otaczającego świata. Realny świat, zewnętrzny wobec subiektywności jednostek i doświadczania owej zewnętrzności, jawi się jako stały w swej oczywistości i uporządkowaniu. Stan, a nie dynamicznie przebiegający proces. Teoretyczny zwrot ku przestrzeni przynosi krytyczną ocenę takiego rozumowania i porzucenie myślenia o przestrzeni w tych kategoriach. Nowe ujęcie proponowane przez przestrzennie zorientowaną teorię, silnie akcentując złożony i relacyjny charakter rzeczywistości, stawia znak równości pomiędzy jej wymiarem przestrzennym i temporalnym. Wszelkie fenomeny społeczne, takie jak ludzie, rzeczy, relacje powinny być opisywane jako osadzone zarazem w czasie i przestrzeni. Przestrzeń konceptualizowana jest jako emergentna i relacyjnie konstruowana, powstająca w ciągłym procesie stawania się. Tworzona przez splot relacji i wzajemnych powiązań, różnorodna, otwarta i nigdy nieukończona, pozostaje niedomknięta .

Donnan i Wilson zwracają uwagę na fakt, że istotną rolę w procesie kształtowania nowego sposobu myślenia o przestrzeni odegrała antropologia kulturowa. Przejście z okresu nowoczesności do społeczeństwa ponowoczesnego przedstawiają oni jako moment stymulujący pogłębioną refleksję nad kulturą, w rezultacie czego nastąpiło uwolnienie pojęcia przestrzeni, miejsca i czasu od zatożeń dotyczacych ich powiązań z takimi, postrzeganymi jako naturalne, jednostkami, jak naród, państwo, tożsamość i kultu$\mathrm{ra}^{7}$. Pojęcie przestrzeni staje się nośną metaforą, służącą do porządkowania i przedstawiania społecznych fenomenów. Przestrzeń rozumiana jest przez Donnana i Wilsona jako abstrakcyjna idea, jaka mają ludzie, dotyczaca tego, gdzie określone rzeczy powinny znajdować się w fizycznej i kulturowej relacji ze soba. W tym sensie przestrzeń jest konceptualizacja wyobrażonych fizycznych powiązań, które dostarczają znaczeń spoteczeństwu. $Z$ kolei miejsce jest określoną przestrzenia, w której żyja ludzie; zawiera w sobie zarówno ideę, jak i rzeczywistość odnosząca się do tego, gdzie określone rzeczy się znajdują. Symboliczny, umowny charakter przestrzeni dopełnia kategoria miejsca, wnosząc do niej bezpośrednie odniesienie do rzeczywistości. Tym samym miejsce niejako lokuje wykoncypowaną przestrzeń w faktycznym, materialnym środowisku. Dopiero zderzenie idei z realnym życiem pozwala ukazać społeczną genezę pojęcia przestrzeni, odsłaniając jej polityczne i ekonomiczne uwarunkowania. Acz najważniejszym pozostaje fakt, że przestrzeń może być przekształcona w miejsce dzięki temu, iż uzyskuje bezpośrednie odniesienie do ludzkiej egzystencji. To ludzkie doświadczenia mają moc wydobywania miejsc z przestrzeni. To człowiek, kreując swój świat życia codziennego, podejmując proces rozumienia, oswaja przestrzeń, tworzac z niej miejsce. Miejsce jest zatem pochodna przeżycia i doświadczenia?.

D. Massey, For Space, London 2005, s. 58-59.

H. Donnan, T.M. Wilson, Granice tożsamości, narodu..., s. 25.

8 Tamże.

9 M. Banaszkiewicz, Kulturowe krajobrazy pamięci, [w:] Przesztość we wspótczesnej narracji kulturowej. Studia i szkice kulturoznawcze, t. 2, red. P. Plichta, Kraków 2011, s. 41. 
Redefiniowanie funkcji granic w wyniku rozwoju technologii oraz nasilających się procesów globalizacji skutkuje zacieraniem granic w społecznej świadomości. Znajduje to wyraz w latwości przekraczania przestrzeni oraz podważania sensu i niwelowania wszelkich podziałów. Rozpuszczanie granic dokonuje się przede wszystkim za sprawą uwolnienia przestrzeni od jej bezpośrednich odniesień terytorialnych. Zastępowanie realnej przestrzeni przestrzenią wirtualną sprawia, że wszelka lokalizacja staje się prowizoryczna i jedynie tymczasowa. W kontekście dokonujących się zmian, teoretyczne rozdzielenie pojęć przestrzeni i miejsca zyskuje na znaczeniu.

\section{KULTUROWE ATRYBUTY KRAJOBRAZU}

Pojęcie krajobrazu (landscape) „przywędrowato” ${ }^{10}$ do teorii społecznej stosunkowo niedawno, przede wszystkim za sprawą geografii i nauk o sztuce. Zostało wprowadzone i dostosowane do przedmiotu badań, najczęściej zyskując formę krajobrazu kulturowego. Dzisiaj krajobraz jest metaforą dosyć chętnie i z pożytkiem stosowaną w naukach społecznych. Wzrost zainteresowania tym pojęciem wiąże się zarówno z dowartościowaniem tej kategorii w refleksji o rzeczywistości kulturowej, jak i z radykalnym jej redefiniowaniem, co zaowocowało rozszerzeniem pola badań nad wpływem kultury na przestrzeń fizyczną. Szczególnie inspirujące przemyślenia na temat krajobrazu wyszły prawie sto lat temu spod pióra Georga Simmla. W eseju Filozofia krajobrazu Simmel opisuje fundamentalne znaczenie krajobrazu dla procesu indywidualizowania i oswajania przestrzeni życia. Fenomen krajobrazu jako efekt obcowania z naturą ukazuje się w bogactwie swej różnorodności, zmienności i jako taki może przybierać bardzo różną formę. Tworzywem krajobrazu są cząstki środowiska naturalnego, ale rozmaite rzeczy rozpościerajace się obok siebie na kawatku ziemi, gdy ogladaćje bezpośrednio, nie stanowia jeszcze krajobrazu ${ }^{11}$. Fragmentaryczny ogląd rzeczy staje się krajobrazem, pewną ograniczoną ramą postrzegania całością, dopiero wówczas, gdy zostanie indywidualnie wyodrębniony z niepodzielnej jedności natury ${ }^{12}$. Warunkiem stworzenia tej całości jest zapośredniczenie osobowe, ponieważ to $w$ świadomości musi zarysować się nowa, jednolita catość, nadrzędna wobec poszczególnych elementów, niezwiąana zich specyficznymi znaczeniami i nieztożona z nich w sposób mechaniczny - i dopiero to jest krajobraz ${ }^{13}$. Percepcję środowiska naturalnego, w ramach której powstają krajobrazy, porównuje Simmel do tworzenia dzieła sztuki. Krajobraz powstaje z oglądu natury, jest chwilowym, estetycznym i emocjonalnym jej uchwyceniem w subiektywnym spojrzeniu ludzkim. Simmel upatruje genezy krajobrazu w ludzkiej świadomości, która określa sposób

10 Krajobraz jest jednym z tych pojęć, które dobrze ilustrują wędrówkę pojęć dokonującą się obecnie $\mathrm{w}$ humanistyce. Ten aspekt interdyscyplinarności został opisany przez Mieke Bal w pracy Wędrujące pojęcia w naukach humanistycznych. Krótki przewodnik, przeł. M. Bucholc, Warszawa 2012.

11 G. Simmel, Filozofia krajobrazu, przeł. M. Łukasiewicz, [w:] tegoż, Most i drzwi. Wybór esejów, Warszawa 2006, s. 292.

12 Tamże, s. 293.

13 Tamże, s. 292. 
postrzegania świata, twierdząc, że krajobraz powstaje tylko wtedy, gdy życie pulsujące w ogladzie i odczuciu odrywa się od jednolitego bytu natury, wyodrębnia, i na nowej ptaszczyźnie samo z siebie znown otwiera się na owo wszech-życie, gotowe w swoich określonych granicach zawrzeć byt bezgraniczny ${ }^{14}$.

Krajobraz jako dynamiczna kompozycja elementów tworzących całość posiada własną semantykę i określoną formę uporządkowania. Przyczyna niezbywalnie dynamicznego charakteru całości tkwi w powiązaniu elementów i relacjach wzajemnego oddziaływania. Pojęcie krajobrazu stwarza szansę pełniejszego ukazania przestrzeni, zarówno w jej materialnym wymiarze, jako przestrzeni geograficznej, jak również kulturowej, symbolicznej i wyobrażonej. Przestrzeń wyobrażona może, choć nie musi, posiadać odniesienie do przestrzeni fizycznej. Wyobrażenia jako manifestacja świadomości społecznej są wytworem ludzkiej aktywności, to w nich usytuowane zostały formy pamięci zbiorowej, sposób postrzegania i nadawania znaczenia przestrzeni. Krajobraz kulturowy powinien być ujmowany i poznawany jedynie w kategoriach procesu i zmiany, ponieważ stanowi szczególny rodzaj ożywionej przestrzeni, przez kogoś zamieszkanej i posiadającej kontekstualnie określone znaczenie. Kulturowe krajobrazy kształtowane są środowiskowo, $\mathrm{w}$ procesie historycznego trwania, kultywowania bądź zmiany tradycyjnych wzorów i wartości, ale także w sferze indywidualnych wyobrażeń i jednostkowych doświadczeń.

W czasach globalizacji, rozmywania i otwierania granic, gdy następuje radykalny wzrost społecznej mobilności, zdolność ukazania przestrzeni w jej dynamicznym kształcie okazuje się szczególnie przydatna. Zwracając uwagę na ten fakt, Arjun Appadurai wykorzystuje pojęcie krajobrazu do opisania przepływów kulturowych w kontekście procesów globalizacji. W pracy Nowoczesność bez granic. Kulturowe wymiary globalizacji Appadurai podejmuje analizę współczesności przez pryzmat kultury globalnej, kładąc nacisk na procesy deterytorializacji i destabilizacji tradycyjnych form życia społecznego. Wymowa globalizacji zostaje przez niego utożsamiona z przepływami ludzi, informacji i dóbr. Globalizacyjne przepływy, które cechuje przygodność i chaotyczność, destabilizują społeczny i kulturowy ład. Przepływy posiadają realny wpływ na to, jakie działania podejmują ludzie, jak postrzegają siebie i świat, w którym żyją. To one są główną siłą tworzenia nowych sposobów życia. Wynikająca z kulturowych przepływów transnarodowa perspektywa, łatwość przekraczania granic oraz masowe migracje ludności mają istotny wpływ na osłabienie roli państw narodowych i zakłócają proces reprodukcji społecznego porządku. Deterytorializacja kultur, która jest efektem płynnej i permanentnie zmiennej natury procesów globalizacji, przejawia się - jak twierdzi Appadurai - w postaci etnokrajobrazów (ethnoscapes) ${ }^{15}$, które stanowią jeden z pięciu wymiarów globalizacji. Pozostałe z wymienionych przez niego krajobrazów to: krajobrazy medialne (mediascapes); krajobrazy technologiczne (technoscapes); krajobrazy finansowe (financescapes) i krajobrazy ideologiczne (ideoscapes). Globalne prze-

14 Tamże, s. 295.

15 Tłumaczenie oryginalnego terminu, który wprowadził Appadurai, jest niejednoznaczne. W polskiej literaturze przedmiotu stosowane są dwie formy: etnoobrazy i etnokrajobrazy. Decyduję się na drugi wariant, ponieważ uważam, że jest on bliższy argumentacji, którą rozwijał Appadurai. 
pływy treści kulturowych ukazane zostały tu jako splot oddziałujących na siebie krajobrazów. Wymienione krajobrazy przenikają się i dopełniając się wzajemnie, tworzą coś na kształt układanek z klocków, które odzwierciedlają społecznie tworzone wielorakie światy wyobrażone, w których przyszło żyć ludziom ${ }^{16}$.

Etnokrajobrazy powstają jako rezultat ludzkiej i grupowej mobilności w przestrzeni, tak geograficznej, jak i społeczno-kulturowej. Tworzone są przez przemieszczające się grupy ludzi, które cechuje odmienność kulturowa i brak zakorzenienia w rodzimej wspólnocie terytorialnej. Oblicze współczesnego świata jest zdefiniowane przez ruch, a sita napędowa dynamiki globalnych systemów kulturowych sa relacje pomiędzy potokami przemieszczająych się ludzi, technologii, finansów, informacji i ideologii ${ }^{17}$. Nasilenie ruchliwości w wymiarze przestrzennym i społecznym sprawia, że świat, w którym żyjemy, jest coraz bardziej heterogeniczny kulturowo. Prowadzi to do osłabienia terytorialnych wspólnot lokalnych, które w wyniku globalnych przepływów stają się coraz bardziej nasycone obcymi im kulturowo treściami, ludźmi i grupami etnicznymi. Komponenty globalnych przepływów kultury układają się w wieloperspektywiczny i złożony konstrukt, kulturową mozaikę składającą się z odmiennych kulturowo, społecznie i politycznie elementów.

Przestrzeń wokół granic to sfera wzajemnych powiązań, wymiany dóbr i informacji, manifestowania i ścierania się różnic kulturowych i społecznych. Przygraniczne krajobrazy kształtowane są przez obecność i wzajemne oddziaływanie szeregu różnorodnych czynników. Wprowadzenie pojęcia krajobrazu zasadniczo zmieniło dotychczasowy sposób myślenia o granicy. Uwagę badaczy w coraz większym stopniu przykuwa teraz różnorodność procesów społecznego wytwarzania granic, pozostających w relacji do szeroko rozumianej przestrzeni politycznych działań. $\mathrm{O}$ istocie tych procesów niewiele można powiedzieć, bazując jedynie na jednoznacznie ustalonych i trwale zdefiniowanych konfiguracjach granic politycznych i terytorialnych. Zrozumienie natury i znaczenia granic między państwami czy narodami wymaga w równym stopniu odwoływania się do kulturowych, ekonomicznych i społecznych uwarunkowań. A to oznacza konieczność rozpoznania całego szeregu zjawisk i relacji zachodzących zarówno na poziomie makrostrukturalnym, jak również - jeżeli nie przede wszystkim - w mikroskali, na poziomie doświadczeń i interakcji grupowych oraz międzyludzkich. Dostrzeganie wielowymiarowego charakteru procesów globalizacyjnych i świadomość konsekwencji, jakie z tego wynikają, ma istotny wpływ na sposób definiowania granicy jako dynamicznej przestrzeni relacji.

\section{BORDERSCAPES - KRAJOBRAZY PRZYGRANICZNE}

Zmiany, które dokonały się w sposobie konceptualizowania granic, ukazują rosnące zainteresowanie badaczy alternatywnymi koncepcjami ich poznawania. Wraz z coraz częściej przywoływaną retoryką świata bez granic następuje stopniowe neutralizowanie

\footnotetext{
16 A. Appadurai, Nowoczesność bez granic. Kulturowe wymiary globalizacji, przeł. Z. Pucek, Kraków 2005, s. 51-52.

17 Tamże, s. 72
} 
terytorialnych koncepcji ujmujących granice jako linie rozdzielające terytoria państw. Uwaga badaczy w znacznie większym stopniu koncentruje się obecnie na społeczno-kulturowych uwarunkowaniach funkcjonowania i transformacji granic. Koncepcja borderscapes stanowi próbę uzupełnienia i wzbogacenia dotychczasowego sposobu myślenia o granicach poprzez podkreślenie roli społecznych i kulturowych aspektów kształtowania przestrzeni wokół granic. Termin borderscape został wprowadzony do studiów nad granicami w latach 90. Do idei krajobrazów przygranicznych jako jedni z pierwszych odwoływali się wówczas Elena Dell'Agnese i Anssi Paasi, a kolejne lata przyniosły wyraźny wzrost zainteresowania tym pojęciem wśród badaczy granic. Refleksja nad etymologią terminu borderscape przywodzi na myśl pokrewne mu wyrażenie krajobrazu. Pojęcie krajobrazu, posiadające dużo szersze znaczenie i znacznie wcześniej spopularyzowane w nauce i sztuce, odsyła do nowej konwencji postrzegania przestrzeni, która stanowi egzemplifikację spotkania geografii z kulturą i polityką.

Ostatnie dwudziestolecie to czas radykalnych zmian politycznych, które znalazły odbicie w poszukiwaniach nowych rozwiązań w studiach nad granicami. Teoretyczne studia nad problemem granic we współczesnym świecie, pogłębiona refleksja nad naturą granic oraz redefiniowanie ich funkcji to wyzwanie, które stoi przed badaczami różnych dyscyplin. Chiara Brambilla, wyraźnie optując za koncepcją borderscapes, podkreśla krytyczny potencjał nowego podejścia do badania granic oraz jego interdyscyplinarną proweniencję. Interdyscyplinarny charakter badań, niejednokrotnie postulowany przez badaczy, stwarza szansę przezwyciężenia schematyzmu dotychczasowych rozważań. Krytyczna analiza uświadamia konieczność odrzucenia jednoznacznych, rozstrzygających sposobów definiowania granic jako obiektów rzeczywistości i prowadzi do sproblematyzowania pojęcia granicy. Dlatego też o tym, czym jest granica, jak jest postrzegana i jaką pełni rolę, orzekać można jedynie post factum na podstawie studiów konkretnego wycinka rzeczywistości. Pozwala to na odtworzenie obrazu realnie istniejących granic w całej ich różnorodności i dynamice. Borderscapes jako egzemplifikacja nowego podejścia do badania specyfiki granic i pograniczy umożliwia poznanie procesów zachodzących w obszarze przygranicznym w ich społeczno-kulturowym kontekście. Perspektywa borderscapes ukazuje polityczne zaangażowanie studiów nad granicami, prowadzi do rozpoznania procesów inkluzji i ekskluzji w ich etycznym i normatywnym wymiarze. Ponadto, znosząc brzemię imperatywu terytorialnego, daje możliwość uchwycenia oddziaływania granicy w znacznie szerszym odniesieniu, a zatem wszędzie tam, gdzie stanowione, przekształcane czy znoszone są granice $^{18}$.

Brambilla podejmuje refleksję nad koncepcją borderscapes, rozpatrując jej walory $\mathrm{w}$ trzech aspektach - ontologicznym, epistemologicznym i metodologicznym. Sedno nowego podejścia, alternatywnego wobec modernistycznych koncepcji granicy, sprowadza się do sformułowania niekonwencjonalnej odpowiedzi na fundamentalne pytanie: czym jest granica? Definiowanie granic i wyznaczanie zakresu ich występowania ciągle

18 Por. Ch. Brambilla, Exploring the Critical Potential of the Borderscapes Concept, „Geopolitics” 2015, vol. 20 , nr 1 . 
budzi liczne wątpliwości i kontrowersje. Dostrzeganie nie tylko terytorialnego sensu granic, ale rozszerzenie pola analizy o granice symboliczne, prowokuje do stawiania nowych pytań o to, jak są pojmowane i gdzie sytuowane są granice. Brambilla, przywołując argumentację sformulowaną przez Suvendrini Pererę, akcentuje przestrzenną i konceptualną złożoność granic. Współczesne granice ze względu na ich nietrwałość i wieloaspektowość nie mogą być już analizowane jako nieruchoma i stabilna przestrzeń. Zmiana optyki skłania do rozumienia granic jako społecznie negocjowanych konstruktów, dyskursów i relacji ciągle wytwarzanych w społecznej praxis i niewyczerpanych w swym potencjale. Granica jako linia podziału między terytoriami państw narodowych wyznacza swoistą, spluralizowaną w swym charakterze przestrzeń. Jest miejscem styku nie tylko różnych kultur i krajów, ale także istnienia odrębnych tożsamości i podziałów wynikających ze społecznej przynależności. Specyfika tej przestrzeni jest określona nie tyle przez sąsiedztwo politycznych i kulturowych różnic, ale przede wszystkim przez przynależną jej entropię i mobilność. Płynność i różnorodność granic państwowych w dobie globalizacji i transnacjonalnych przepływów zmusza do redefiniowania przypisywanego im znaczenia. W efekcie nacisk położony jest na ukazanie, jak granice są tworzone, utrzymywane bądź zmieniane, zarówno w wymiarze deklaracji i działań politycznych, jak i na płaszczyźnie doświadczenia ludzi żyjących w ich ramach i ich społecznych praktyk ${ }^{19}$.

Próba sformułowania odpowiedzi na wcześniej postawione pytanie o to, jak pojmowana jest granica, zmusza do wyartykułowania przyjmowanych założeń ontologicznych. Fenomen ponowoczesności wyraźnie kojarzony jest z płynnością i brakiem granic. Zanikanie granic w postmodernistycznej optyce traktowane jest jako rezultat społecznej transformacji rzeczywistości, swoisty znak czasów, w których żyjemy. Przypisywanie granicom procesualnej i relacyjnej natury wychodzi naprzeciw takim poglądom. Dlatego też postrzeganie granic jako efemerycznych bytów, społecznie wytwarzanych i modyfikowanych pod wpływem wydarzeń, Brambilla zdecydowanie przedkłada nad realistycznie zorientowaną ontologię granic. Uważa, że w dobie globalizacji i transnarodowych przepływów o granicach możemy mówić jedynie jako o tymczasowych, społecznie konstruowanych fenomenach. Współczesne granice ukazują w pełni swą płynność, podatność na zmianę, niedookreślone usytuowanie i fluktuację pełnionych funkcji. Odrzucenie realistycznego nastawienia niesie niebagatelne skutki dla wymogów definiowania granic. Zakłada bowiem rozumienie fenomenów rzeczywistości - w tym granic - nie jako odrębnych bytów, istniejących niezależnie od świadomości i działań ludzi, lecz jako społecznie negocjowanych konstruktów, stanowiących wynik jednostkowych i zbiorowych działań. Przedmiotem poznania nie jest więc rzeczywistość jako taka, ale proces jej kreowania i to, jak przedstawia się ona w świadomości społecznej. Przyjęcie alternatywnej wobec realizmu konstrukcjonistycznej ontologii granic oznacza radykalną zmianę postrzegania związku pomiędzy sferą politycznych praktyk przynależności bądź wykluczenia (inclusion-exclusion) a wyobrażeniami kulturowymi, które potwierdzają i komunikują znaczenie owych praktyk ${ }^{20}$.

19 Tamże, s. 19.

20 Tami̇e, s. 26. 
Eksploracja granic z nastawieniem borderscapes - dowodzi Brambilla - umożliwia prowadzenie krytycznej analizy na różnych poziomach. Pozwala na osadzenie rozważań o naturze granic w wymiarze normatywnym oraz ocenę etycznych, prawnych, empirycznych założeń i racji, stosowanych do uzasadniania, poznawczych oraz opartych na doświadczeniach, szczególnych zasad, zgodnie z którymi wizje i sposoby istnienia granic są artykułowane. Po wtóre, koncepcja borderscapes prowadzi do przyjęcia tezy, że granice uwikłane są w spory i konflikty, obejmujące liczne strategie sprzeciwu wobec dominujących dyskursów i sprawowanych w ich ramach praktyk kontroli. Nadto na podkreślenie zasługuje fakt, że intencją przyświecającą idei borderscapes jest wyeksponowanie politycznego wymiaru granic. Kontekst geopolityczny odgrywa bowiem istotne znaczenie dla procesów przystosowania i kontestacji, które zachodzą w przestrzeni przygranicznej ${ }^{21}$. W efekcie takie nastawienie badawcze pozwala na zgromadzenie różnorodnej, odkrywającej wiele istotnych aspektów wiedzy o granicach. Przekonuje także o konieczności postrzegania granic nie tylko jako elementu makrostrukturalnej polityki międzypaństwowej, ale uświadamia również potrzebę szerszego spojrzenia. Dopiero wówczas pojawia się możliwość uchwycenia oddziaływania polityki na sferę codziennych praktyk społecznych.

\section{IMPLIKACJE METODOLOGICZNE}

Propagowanie nowego podejścia do badania granic wiąże się z formułowaniem expressis verbis niekonwencjonalnych wymogów i procedur metodologicznych. Nacisk położony na dynamiczny i procesualny sens granic pociąga za sobą zainteresowanie głównie metodami o wyraźnym nastawieniu jakościowym, rozwijanymi w paradygmacie interpretatywnym. Przedmiotem badań czyni się bowiem nie obiekty, a procesy konstytuujące społeczny świat, składające się nań działania jednostek i grup, sieci ich wzajemnych powiązań i zależności. Procesualnie zorientowana nauka o granicach, dążąc do poznania dynamicznego aspektu rzeczywistości społecznej, próbuje uchwycić przedmiot swoich badań w działaniu. W efekcie refleksja o rzeczywistości jest orzekaniem nie tyle o tym, jaka jest rzeczywistość, ile próbą pokazania procesu stawania się tworzących ją stanów, a jej poznanie zasadza się na ukazaniu zmiennych w czasie i przestrzeni relacji społecznych. Zadanie teorii nie sprowadza się zatem do ustalania i nazywania istniejących stanów rzeczy ani nawet do udzielania odpowiedzi na pytanie, dlaczego jest tak, jak jest, ale do refleksyjnego monitorowania tego, co się wydarza, rozpoznawania procesów, które tworzą materię społecznego świata. Taka postawa badawcza napotyka na spore trudności, ponieważ uchwycenie procesów społecznego definiowania, negocjowania i uwiarygodniania istniejących granic wymaga włączenia do badań szerokiej gamy czynników.

Koncepcja przygranicznych krajobrazów ukazuje przestrzeń wokół granicy, dążąc do jak najlepszego oddania jej wielowymiarowego charakteru. Jeżeli poznawanie granic

21 Tamże, s. 20. 
nie ma być sprowadzone do sprawnego odczytywania mapy, ale ma na celu wydobycie na światło dzienne wiedzy o złożonych procesach ich tworzenia, to do osiągnięcia tego celu potrzebne jest stosowne instrumentarium. Wszelkie próby konceptualizacji granicy wymagają uzupełnienia projektami badań. Rekomendowane są przede wszystkim pogłębione badania etnograficzne w terenie. Za ich szczególnie interesujący wariant uważa się badania wielostanowiskowe. Brambilla na bazie swoich doświadczeń badawczych wskazuje na użyteczność badań performatywnych (performative approach) i badań z aktywnym uczestnictwem badacza (participatory approach). Siłą wyróżnionych podejść badawczych jest możliwość uchwycenia procesów wytwarzania granic, zarówno poprzez odtwarzanie publicznych dyskursów, jak i zbliżenie się do poziomu doświadczeń i codziennych praktyk. Przyszłość pokaże, na ile mamy do czynienia z kolejną, nową i dlatego atrakcyjną figurą stylistyczną, a na ile jest to rzeczywisty przełom w badaniu granic jako fenomenów społeczno-kulturowych.

\section{BIBLIOGRAFIA}

Appadurai A., Nowoczesnosíc bez granic. Kulturowe wymiary globalizacji, przeł. Z. Pucek, Kraków 2005.

Balibar É., Europe as Borderland, „Environment and Planning D: Society and Space” 2009, vol. 27, nr 2, https://doi.org/10.1068/d13008.

Banaszkiewicz M., Kulturowe krajobrazy pamięci, [w:] Przesztość we wspótczesnej narracji kulturowej. Studia i szkice kulturoznawcze, t. 2, red. P. Plichta, Kraków 2011.

Barth F., Grupy i granice etniczne: spoteczna organizacja różnic kulturowych, przeł. M. Głowacka-Grajper, [w:] Badanie kultury. Elementy teorii antropologicznej. Kontynuacje, red. M. Kempny, E. Nowicka, Warszawa 2004.

Borderscaping: Imaginations and Practices of Border Making, red. Ch. Brambilla, J. Laine, J.W. Scott, G. Bocchi, New York 2016.

Brambilla Ch., Exploring the Critical Potential of the Borderscapes Concept, „Geopolitics” 2015, vol. 20, nr 1, https://doi.org/10.1080/14650045.2014.884561.

Buchowski M., Granica a uprawianie antropologii - uwagi wstępne..., [w:] Polska-Niemcy. Pogranicze kulturowe i etniczne, Archiwum Etnograficzne, t. 42, red. M. Buchowski, A. Brencz, Wrocław-Poznań 2004.

Critical Border Studies. Broadening and Deepening the 'Lines in the Sand' Agenda, red. N. Parker, N. Vaughan-Williams, New York 2014.

Donati P., Relational Sociology. A New Paradigm for Social Sciences, London 2011.

Donnan H., T.M. Wilson, Granice tożsamości, narodu, państwa, przeł. M. Głowacka-Grajper, Kraków 2007.

Gupta A., Ferguson J., Poza „kulturę”: przestrzeń, tożsamośc i polityka różnicy, przeł. J. Giebułtowski, [w:] Badanie kultury. Elementy teorii antropologicznej. Kontynuacje, red. M. Kempny, E. Nowicka, Warszawa 2004.

Ingold T., Kultura i postrzeganie środowiska, przeł. G. Pożarlik, [w:] Badanie kultury. Elementy teorii antropologicznej, red. M. Kempny, E. Nowicka, Warszawa 2003. 
Kurczewska J., Spaces and Borders as Social Values, [w:] Borders and Fields, Cultures and Places: Cases from Poland, red. D. Wojakowski, Kraków 2008.

Massey D., For Space, London 2005.

Newman D., Anssi P., Podziaty i sąsiedztwa w ponowoczesnym świecie. Narracje granic w geografii politycznej, przeł. B. Czepil, „Pogranicze. Polish Borderlands Studies” 2013, vol. 1, nr 1. Opiłowska E., Od linii granicznych do krajobrazów przygranicznych. Konceptualizacje i badania granic i pograniczy, [w:] Polskie pogranicza w procesie przemian IV, red. Z. Kurcz, Wrocław 2017.

Paasi A., Boundaries as Social Processes: Territoriality in the World of Flows, [w:] Boundaries, Territory and Postmodernity, red. D. Newman, London 1999.

Paasi A., Bounded Spaces in a 'Borderless World': Border Studies, Power and the Anatomy of Territory, "Journal of Power” 2009, vol. 2, nr 2, https://doi.org/10.1080/17540290903064275.

Paasi A., The Shifting Landscapes of Border Studies and the Challenge of Relational Thinking, [w:] The New European Frontiers. Social and Spatial (Re)Integration Issues in Multicultural and Border Region, red. M. Bufon, J. Minghi, A. Paasi, Newcastle upon Tyne 2014.

Perera S., A Pacific Zone? (In)Security, Sovereignty, and Stories of the Pacific Borderscape, [w:] Borderscapes. Hidden Geographies and Politics at Territory's Edge, red. P.K. Rajaram, C. Grundy-Warr, Minneapolis 2007.

Rajaram P.K., Grundy-Warr C., Borderscapes. Hidden Geographies and Politics at Territory's Edge, Minneapolis 2007.

Simmel G., Filozofia krajobrazu, [w:] G. Simmel, Most i drzwi. Wybór esejów, przeł. M. Łukasiewicz, Warszawa 2006.

Dr Irena SZLACHCICOWA - adiunkt w Instytucie Socjologii Uniwersytetu Wrocławskiego. Jej główne obszary zainteresowań badawczych to teoria społeczna, socjologia pogranicza, metodologia badań jakościowych. 